\title{
Sistem Informasi Manajemen Penjualan Obat pada Aplikasi Halodoc
}

\author{
Ranti FEBRIANTI \\ Fakultas Ekonomi, STIE STEMBI Bandung Business School, \\ Jalan Buah Batu No.26 Burangrang Kec. Lengkong Kota Bandung, Jawa Barat, Indonesia \\ Aliya Devi RAMADYTA \\ Fakultas Ekonomi, STIE STEMBI Bandung Business School, \\ Jalan Buah Batu No.26 Burangrang Kec. Lengkong Kota Bandung, Jawa Barat, Indonesia \\ aliyadeviramadyta20@student.stembi.ac.id \\ Zen N VIRGIAWAN \\ Fakultas Ekonomi, STIE STEMBI Bandung Business School, \\ Jalan Buah Batu No.26 Burangrang Kec. Lengkong Kota Bandung, Jawa Barat, Indonesia \\ zennvirgiawan@gmail.com \\ Ricky FIRMANSYAH \\ Program Studi IImu Komunikasi, Universitas Ars, \\ Jalan Sekolah Internasional No. 1-2 Bandung, Jawa Barat, Indonesia \\ ricky@ars.ac.id
}

\section{Article's history:}

Received 3 January 2021; Received in revised form 3 February 2021; Accepted 15 February, 2021; Published 28 February 2021. All rights reserved to the Lembaga Otonom Lembaga Informasi dan Riset Indonesia (KITA INFO dan RISET).

Suggested citation:

Febrianti, R., Ramadyta, D.A., Virgiawan, N.Z., Firmansyah, R. 2021. Sistem Informasi Manajemen Penjualan Obat pada Aplikasi Halodoc. JEMSI (Jurnal Ekonomi, Manajemen, dan Akuntansi), Volume 7 (1): 27-32. DOI: https://doi.org/10.35870/jemsi.v7i1.517.

\begin{abstract}
ABSTRAK:
Halodoc merupakan aplikasi pertama di Indonesia yang berkaitan dengan bidang kesehatan, aplikasi ini hadir sebagai inovasi baru dari perkembangan teknologi. Selain untuk konsultasi, halodoc juga menyediakan fitur penjualan obat seperti di apotek pada umumnya, melalui aplikasi Halodoc ini setiap orang yang memiliki keluhan ataupun membutuhkan obat-obatan tetapi terkendala dengan waktu hanya perlu menggunakan aplikasi halodoc. Metode yang digunakan pada penelitian ini adalah deskriptif analisis dengan hasil yaitu sebagian besar pengguna menyatakan menggunakan Aplikasi Halodoc saat berbelanja/berkonsultasi sangat membantu dan memudahkan para pengguna untuk mencari obat/dokter yang mereka butuhkan.
\end{abstract}

Kata Kunci: Aplikasi; Inovasi; Konsultasi; Obat.

JEL Classification: L86; D83.

\section{PENDAHULUAN}

Perkembangan sistem informasi manajemen pada era globalisasi saat ini merupakan suatu hal yang sangat dapat memudahkan segala pekerjaan ataupun kegiatan bagi setiap orang. Dengan adanya sistem informasi manajemen ini menjadikan hadirnya berbagai fasilitas pelayanan untuk memudahkan pengguna dalam beraktivitas, salah satunya hadirnya sebuah aplikasi yang bernama "Halodoc". Halodoc ini merupakan aplikasi pertama di Indonesia yang tentunya berkaitan dengan bidang kesehatan, aplikasi ini hadir sebagai inovasi baru dari perkembangan teknologi (Sudirman, 2020).

Aplikasi Halodoc ini sudah tersebar luas dikalangan masyarakat terlebih aplikasi ini sangatlah berperan penting dikarenakan penggunaannya yang sangat mudah. Banyak hal menarik yang dapat kita temui di aplikasi 
Halodoc ini seperti konsultasi dengan dokter hingga penyediaan obat-obatan. Aplikasi ini menargetkan kepada masyarakat yang membutuhkan pelayanan dengan cepat, mudah dan efektif sehingga pasien yang memerlukan kebutuhan hanya perlu mempunyai aplikasi pada smartphonenya dan tidak perlu mendatangi tempat praktek dokter (Suryani 2020). Selain untuk konsultasi halodoc juga menyediakan fitur penjualan obat seperti di apotek pada umumnya, melalui aplikasi Halodoc ini setiap orang yang memiliki keluhan ataupun membutuhkan obatobatan tetapi terkendala dengan waktu hanya perlu menggunakan aplikasi halodoc untuk memesan obat-obatan yang dibutuhkan hanya dari rumah saja, pada aplikasi halodoc ini pembelian obat dilakukan secara online dan akan diantarkan langsung kepada pasien. Melihat hal ini membuat peneliti melakukan penelitian tentang sistem informasi manajemen penjualan obat pada aplikasi halodoc (Muliana, $\mathrm{H}, 2020$ ).

\section{TINJAUAN KEPUSTAKAAN}

Penelitian terdahulu yang pertama berjudul "Sistem Informasi Manajemen (SIM) Pembelian dan Penjualan pada apotek Mahkota" yang disusun mahasiswa Program Studi Sistem Informasi Universitas Islam Raden Fatah Palembang oleh Susanti (2015). Penelitian ini dibuat secara khusus untuk Apotek Mahkota menggunakan metodologi pengumpulan data dengan cara observasi dan studi pustaka. Fitur dari sistem penjualan obat tersebut meliputi data obat, penjualan, data supplier, data karyawan, data pembelian, resep obat, laporan penjualan, laporan pembelian, grafik penjualan hingga retur penjualan. Hal yang menjadi batasan dalam penelitian ini adalah sistem informasi yang dikembangkan tidak mencakup resep racikan detail dan keamanan atau security. Penelitian terdahulu yang kedua berjudul "Sistem Informasi Penjualan Apotek "Siaga" Temanggung Berbasis Client-Server" yang disusun oleh mahasiswa Program Studi Informatika Universitas Sanata Dharma Yogyakarta oleh Andri purnomo (2006). Latar belakang dikembangkan sistem informasi ini adalah mengelola proses transaksi penjualan hingga pelanggan melakukan pembayaran berbasis komputer. Metodologi penelitian ini adalah pendekatan terstruktur yaitu analisis dan desain terstruktur.Hal yang menjadi batasan dalam laporan ini dibatasi pada sistem proses pelayanan transaksi penjualan obat yang meliputi penjualan obat dengan resep dan pembuatan laporan-laporan harian ataupun bulanan.

\section{METODE PENELITIAN}

Jenis metode penelitian yang digunakam adalah deskriptif analisis, pengertian dari metode deskriptif analisis menurut (Sugiono: 2015; 29) adalah suatu metode yang berfungsi untuk mendeskripsikan atau memberi gambaran terhadap objek yang diteliti dengan data atau sampel yang telah terkumpul sebagaimana adanya dan membuat kesimpulan dari hasil yang telah dianalisis serta dapat berlaku untuk umum. Dengan kata lain penelitian deskriptif analisis mengambil masalah atau memusatkan perhatian kepada masalah-masalah sebagaimana adanya saat penelitian dilaksanakan, hasil penelitian yang kemudian diolah dan dianalisis untuk diambil kesimpulannya. Menurut Sugiyono (2017:19) Objek Penelitian adalah sasaran ilmiah untuk mendapatlkan data dengan tujuan dan kegunaan tertentu tentang suatu hal yang objektif, valid dan reliable tentang suatu hal (variabel tertentu). Tulisan ini didasari oleh hasil penelitian yang dilakukan dijejaring sosial, tepatnya melalui kuesioner Google Form yang kami bagikan melalui aplikasi Whatsapp, yaitu berupa Grup, Status dan orang yang berada di kontak. Teknik pengumpulan data dengan cara mengajukan pertanyaan tertulis untuk dijawab secara tertulis oleh responden, dan nantinya jawaban responden akan otomatis direkam oleh Google Form, dan dari data itulah kami merangkum.

Masalah yang kami analisis untuk diambil kesimpulannya adalah bagaimana sistem informasi manajemen penjualan obat di aplikasi Halodoc. Kemudian objek yang dianalisis adalah para pembeli/ orang yang pernah membeli, berlangganan membeli obat dan kemungkinan menggunakan Aplikasi Halodoc. Selanjutnya ketika data telah terkumpul maka semua hasil analisis akan dibuat menjadi suatu kesimpulan dan menjadi hasil penelitian.

\section{HASIL PENELITIAN DAN PEMBAHASAN}

Sistem Informasi Manajemen merupakan sistem informasi yang menghasilkan hasil keluaran (output) dengan menggunakan masukan (input) dan berbagai proses yang diperlukan untuk memenuhi tujuan tertentu dalam suatu kegiatan manajemen. Pengembangan Sistem Informasi Manajemen canggih berbasis komputer memerlukan sejumlah orang yang berketrampilan tinggi dan berpengalaman lama dan memerlukan partisipasi dari para manajer organisasi. Secara akademis, istilahnya ini umumnya digunakan untuk merujuk pada kelompok 
metode manajemen informasi yang bertalian dengan otomasi atau dukungan teerhadap pengambilan keputusan manusia, seperti system pendukung keputusan, system pakar dan system informasi eksekutif.

Dengan kata lain Sistem Informasi Manajemen adalah sebagai suatu sistem berbasis komputer yang menyediakan informasi bagi beberapa pemakai dengan kebutuhan yang sama. Para pemakai biasanya membentuk suatu entitas organisasi formal, perusahaan atau sub unit dibawahnya. Informasi menjelaskan perusahaan atau salah satu sistem utamanya mengenai apa yang terjadi di masa lalu, apa yang terjadi sekarang dan apa yang mungkin terjadi di masa yang akan datang. Informasi tersebut tersedia dalam bentuk laporan periodik, laporan khusus dan ouput dari model matematika. Output informasi digunakan oleh manajer maupun non manajer dalam perusahaan saat mereka membuat keputusan untuk memecahkan masalah.

Perancangan, penerapan dan pengoperasian Sistem informasi Manajemen adalah mahal dan sulit. Upaya dan biaya yang diperlukan harus dipertimbangkan dengan sebaik mungkin. Ada beberapa faktor yang membuat Sistem Informasi Manajemen menjadi semakin diperlukan, antara lain bahwa manajer harus berhadapan dengan lingkungan bisnis yang semakin rumit. Salah satu alasan dari kerumitan ini adalah semakin meningkatnya dengan muncunya peraturan dari pemerintah. Maka lingkungan bisnis bukan hanya rumit tetapi juga dinamis. Oleh sebab itu manajer harus membuat keputusan dengan cepat terutama dengan munculnya masalah manajemen dengan munculnya pemecahan yang memadai. Setelah melakukan penyebaran kuesioner secara daring atau online terhadap responden, telah terkumpul data yang memiliki karakteristik responden seperti yang dijelaskan pada table berikut :

Tabel 1. Karakteristik Responden

\begin{tabular}{llc}
\hline 1. Jenis Kelamin & Jumlah & Persentase \\
Laki-laki & 12 & $37,5 \%$ \\
Perempuan & 20 & $62,5 \%$ \\
Usia & 2 & $6,3 \%$ \\
$\quad<17$ tahun & 23 & $71,9 \%$ \\
$17-20$ tahun & 7 & $21,9 \%$ \\
$>20$ tahun & 28 & $87,5 \%$ \\
3. Lama Penggunaan Aplikasi & 1 & $3,1 \%$ \\
$1-6$ bulan & & $6,3 \%$ \\
$7-12$ bulan & & $3,1 \%$ \\
\hline 1 tahun & & \\
2 tahun lebih & &
\end{tabular}

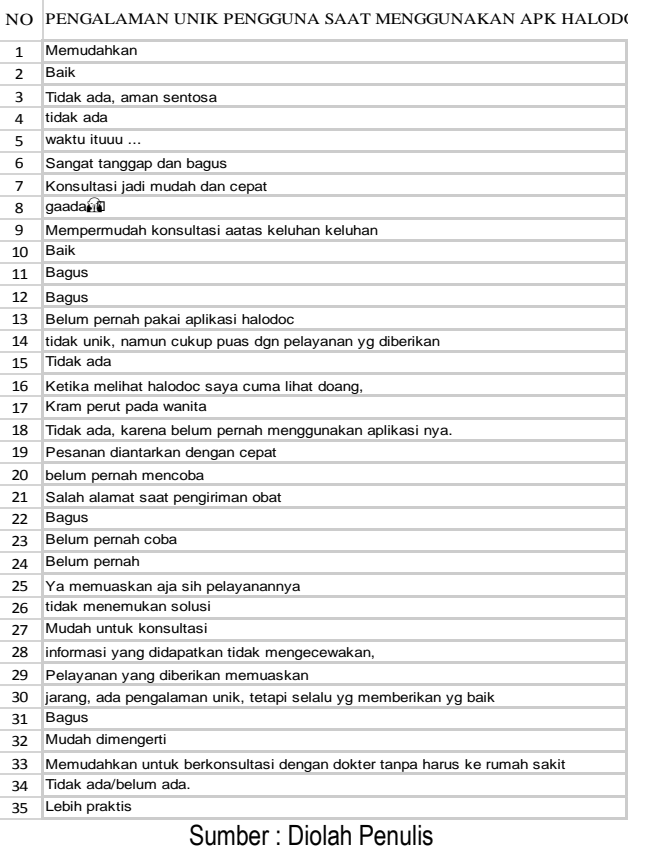


Kesimpulan yang didapatkan dari beberapa tanggapan responden (table 1) mengenai pelayanan yang diberikan pada aplikasi halodoc adalah, pelayanan cukup baik, detail, dan hati hati (tidak asal diagnosis), pelayanan yang diberikan tidak sebatas diagnosis dokter, tetapi dilengkapi dengan fitur pembelian obat yang memudahkan pengguna saat tidak bisa keluar rumah, terutama di masa pandemic seperti ini. Berikut akan kami sajikan data berupa responden masyarakat mengenai Aplikasi Halodoc, sebagai berikut:

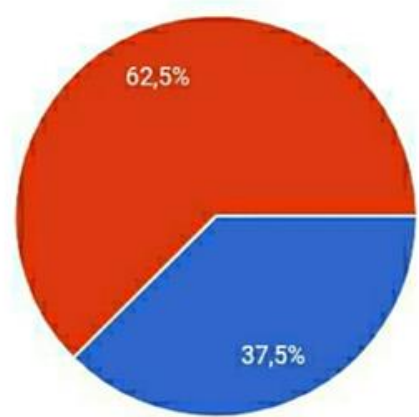

(- Laki-laki

Perempuan

Grafik 1. Persentase Responden terhadap Penggunaan Aplikasi Halodoc

Hasil dari jawaban yang kami dapatkan dari kalangan masyarakat khususnya pada remaja atau pun yang pernah menggunakan Aplikasi Halodoc. Maka hasil dari riset kami menunjukkan bahwa dari 100\% sebesar 62,5\% didapat dari Jenis Kelamin Perempuan dan 37,5\% dari Jenis Kelamin Laki-Laki. Dapat disimpulkan bahwa dari setiap responden lebih banyak pengguna dari kalangan perempuan dibandingkan laki-laki. Hasil jawaban dari 32 orang responden pada kalangan mahasiswa dan pelajar didapatkan data bahwa usia kurang dari 17 tahun hanya berjumlah .. orang atau sekitar $6,3 \%$, usia $17-20$ tahun sekitar .. orang atau $71,9 \%$, adapun yang berusia lebih dari 21 tahun berjumlah .. orang atau sekitar $21,9 \%$. Dapat disimpulkan bahwa yang lebih banyak menggunakan aplikasi tersebut usia 17-20 tahun berjumlah .. atau $71,9 \%$

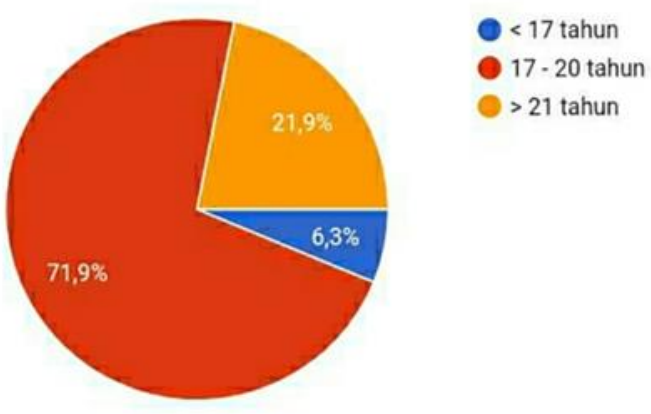

Grafik 2. Persentase Usia Responden

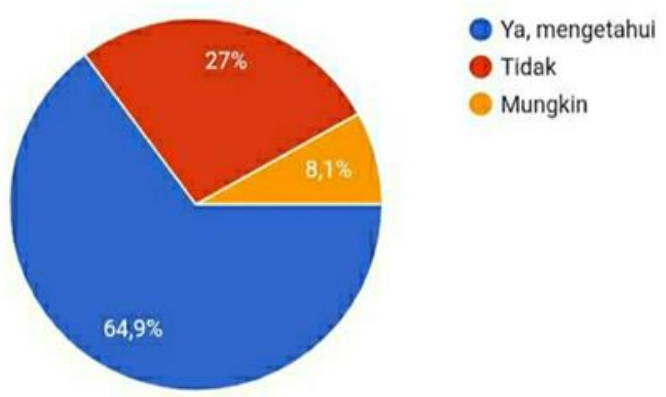

Grafik 3. Persentase Pemahaman Fitur Aplikasi Halodoc

Dari data diatas terlihat bahwa $64,9 \%$ atau 22 orang mengetahui , $27 \%$ atau 10 orang tidak mengetahui, dan $8,1 \%$ atau 3 orang mungkin mengetahui. Maka kesimpulannya dari $100 \%$ atau 35 hanya sekitar 22 orang atau $64,9 \%$ Mengetahui fitur penjualan obat pada aplikasi halodoc. 


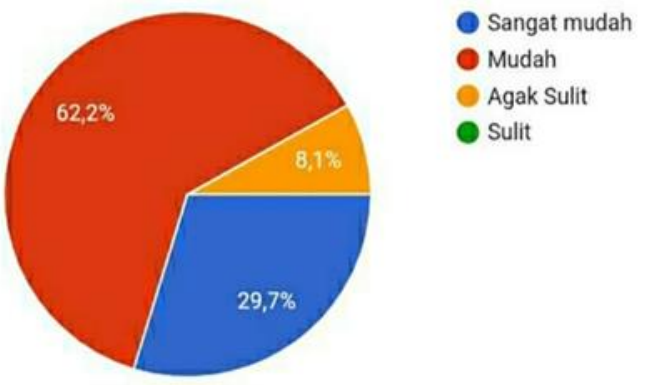

Grafik 4. Persentase Pemahaman Fitur Penjualan Aplikasi Halodoc

Dari data diatas dapat dilihat bahwa $62,2 \%$ atau 23 orang responden menunjukkan bahwa fitur penjualan obat pada aplikasi Halodoc mudah bagi pengguna untuk mengakses kesehatan, 29,7\% atau 11 orang menunjukkan fitur tersebut sangat mudah, dan $8,1 \%$ atau 3 orang menunjukkan fitur tersebut agak sulit. Namun, tidak ada yang menunjukkan fitur tersebut sulit. Maka kesimpulannya Fitur penjualan obat pada aplikasi Halodoc memudahkan pengguna untuk mengakses kesehatan.

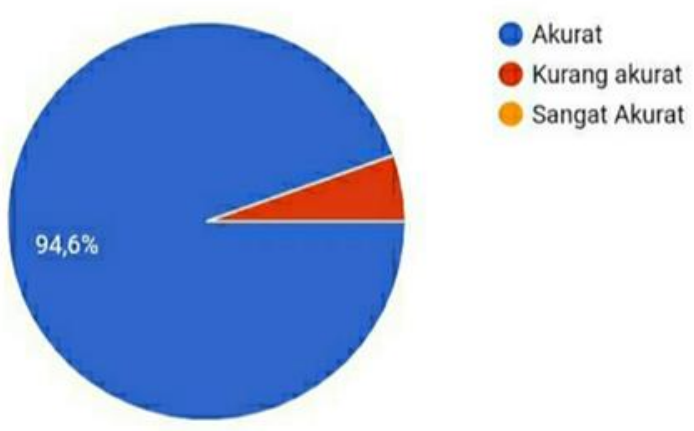

Grafik 5. Persentase Pemahaman Informasi Aplikasi Halodoc

Dari data diatas dapat dilihat bahwa $94,6 \%$ atau 29 orang menunjukkan bahwa informasi yang diberikan aplikasi halodoc Akurat, 5,4\% atau 6 orang menunjukkan informasi yang diberikan aplikasi halodoc Sangat akurat. Maka kesimpulannya Informasi yang diberikan halodoc Akurat. Dengan kata lain, dengan mudahnya informasi yang diberikan kepada pengguna Halodoc, maka pengguna baru ataupun lama akan dengan mudah mengakses aplikasi tersebut untuk kebutuhan seperti membeli obat.

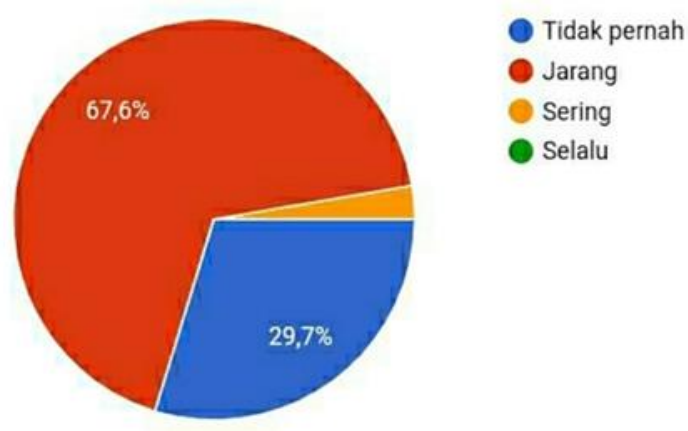

Grafik 6. Persentase Penggunaan Aplikasi Halodoc

Dari data diatas dapat dilihat bahwa $67,6 \%$ atau 25 orang menunjukkan bahwa responden jarang menggunakan aplikasi halodoc, $29,7 \%$ atau 11 orang tidak pernah menggunakan aplikasi halodoc dan 2,7\% atau 4 orang sering menggunakan aplikasi halodoc. Maka kesimpulannya responden jarang menggunakan aplikasi Halodoc. 

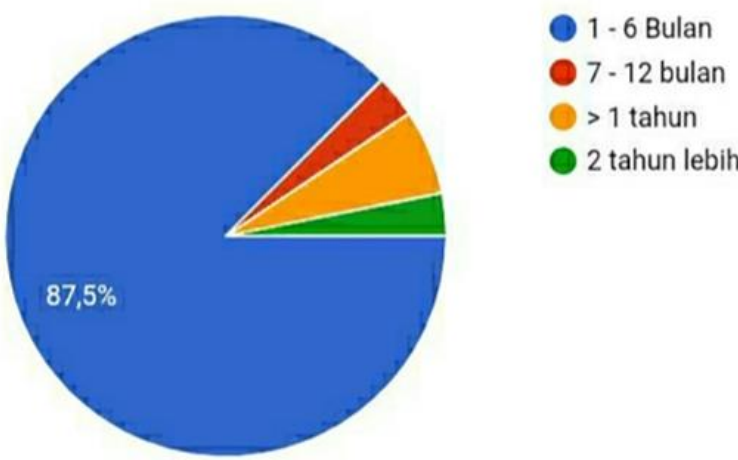

Grafik 7. Persentase Responden Terhadap Lama Penggunaan Aplikasi Halodoc

Dari hasil tersebut dapat dilihat bahwa 28 orang atau $87,5 \%$ responden menggunakan aplikasi halodoc sekitar 1-6 bulan. Maka dapat disimpulkan bahwa $87,5 \%$ dari 100\% pengguna adalah pengguna baru yang menggunakan aplikasi kurang dari 1 tahun. Dari data yang diambil sebagian besar pengguna menyatakan pengalaman menggunakan Aplikasi Halodoc begitu penting untuk digunakan karena penggunaan Aplikasi Halodoc tersebut sangatlah efektif apalagi dengan keadaan di tengah pandemic seperti sekarang ini. Dan sebagian masyarakat beranggapan bahwa menggunakan Aplikasi Halodoc saat berbelanja/berkonsultasi sangat membantu dan memudahkan para pengguna untuk mencari obat/dokter yang mereka butuhkan.

\section{KESIMPULAN}

Aplikasi Halodoc ini sudah tersebar luas dikalangan masyarakat terlebih aplikasi ini sangatlah berperan penting dikarenakan penggunaannya yang sangat mudah. Banyak hal menarik yang dapat kita temui di aplikasi Halodoc ini seperti konsultasi dengan dokter hingga penyediaan obat-obatan. Fitur dari sistem penjualan obat tersebut meliputi data obat, penjualan, data supplier, data karyawan, data pembelian, resep obat, laporan penjualan, laporan pembelian, grafik penjualan hingga retur penjualan. Latar belakang dikembangkan sistem informasi ini adalah mengelola proses transaksi penjualan, konsultasi dengan Dokter terpercaya hingga pelanggan melakukan pembayaran berbasis komputer. Metodologi penelitian ini adalah pendekatan terstruktur yaitu analisis dan desain terstruktur. Pada intinya, penggunaan aplikasi Halodoc sangat memuaskan pelanggan, arti memuaskan adalah banyak masyarakat yang menyukai hal tersebut karena tidak usah repot untuk mengeluarkan tenaga lebih. Terlebih teknologi era sekarang yang makin berkembang pesat akan makin memudahkan para pembeli atau berkonsultasi dengan Dokter.

\section{REFERENSI}

Muliana, H. (2020). Perlindungan Hukum Terhadap Konsumen Dan Pelaku Usaha Dalam Jual Beli Obat Secara Online (Doctoral Dissertation, Universitas Katolik Soegijapranata Semarang).

Sugiyono. 2015. Metode Penelitian Kuantitatif, Kualitatif, dan R\&D. Bandung: Alfabeta.

Sugiyono. 2017. Metode Penelitian Kuantitatif, Kualitatif, dan R\&D. Bandung: Alfabeta.

Susanti, S., Ramadhan, M., \& Fenando, F. (2015). Sistem Informasi Manajemen (SIM) Pembelian dan Penjualan pada Apotek Mahkota. JUSIFO (Jurnal Sistem Informasi), 1(1), 53-60.

Sudirman, A., Muttaqin, M., Purba, R. A., Wirapraja, A., Abdillah, L. A., Fajrillah, F., ... \& Simarmata, J. (2020). Sistem Informasi Manajemen. Yayasan Kita Menulis.

Suryani, N. L. (2020). Covid 19 dan New Norma (L).

Irfan, Moch., Rusdiana,A. 2014. Sistem Informasi Manajemen: CV Pusraka Setia 